\title{
EL ESCALOFRÍO EN LA ÚLTIMA MINIFICCIÓN HISPÁNICA: AJUAR FUNERARIO, DE FERNANDO IWASAKI
}

\author{
Francisca Noguerol (Universidad de Salamanca)
}

\begin{abstract}
Si tu casa es un laberinto y en tu habitación Algo te espera, si cobran vida los garabatos que dibujaste (tan mal) con tiza en la pared de tu pieza, y en el living la cabeza de tu hermana ensucia de sangre la pana del sillón verde; si hay Cosas jugando con tus animales de plástico en la bañadera, no te preocupes, hijita, son solamente pesadillas infantiles, ya vas a crecer, y después vas a envejecer y después no vas a tener más sueños feos, ni te vas a volver a despertar con angustia, no vas a tener más sueños, hijita, ni te vas a volver a despertar (“Sueños de niños", Shua: 99).
\end{abstract}

*Artículo aparecido en Miradas oblicuas en la narrativa latinoamericana contemporánea: límites de lo real, fronteras de lo fantástico. Jesús Montoya y Ángel Esteban eds. Madrid, Iberoamericana, 2009, pp. 195-217. ISBN: 978-84-8489-467-4.

Un encuentro de título tan sugerente como "Miradas oblicuas en la narrativa latinoamericana: fronteras de lo real, límites de lo fantástico" me ha parecido especialmente adecuado para analizar el resurgimiento del terror en la más reciente minificción hispánica.

En las siguientes páginas me acercaré a este fenómeno repasando las principales claves de la literatura gótica, destacando su relevancia en la narrativa más reciente y atendiendo a un título maestro en la provocación del escalofrío: Ajuar funerario (2004), conjunto de 89 microrrelatos firmado por el escritor hispanoperuano Fernando Iwasaki que ha obtenido tanto éxito editorial -ya va por la cuarta edición en Páginas de Espuma- como cibernético -se encuentra citado una y otra vez en la red- y crítico: otros autores han homenajeado el volumen en sus recientes minificciones ${ }^{1}$ mientras los comentarios sobre el mismo se suceden a gran velocidad. Así, en el periodo transcurrido entre el momento en que expuse este trabajo -abril de 2008- y hoy, 13 de noviembre del mismo año, he podido escuchar ya tres excelentes ponencias que analizaron el volumen mientras ha aparecido un nuevo artículo sobre el mismo en la red. ${ }^{2}$

\section{EL MIEDO EN LA LITERATURA}

\footnotetext{
${ }^{1}$ Es el caso de José Antonio Francés, que inicia Miedo me da (78 relatos de humor y espanto) (2007) con una cita de Ajuar funerario, mientras Andrés Neuman dedica a Iwasaki su estupendo microrrelato "Novela de terror", con un contenido tan escueto como perturbador: "Me desperté recién afeitado" (Neuman: 111).

2 “¡La muerte le sienta tan bien!”, de la profesora Ángeles Mateo del Pino, ponencia presentada en las Jornadas Internacionales de Literatura y crítica MINIFICCIÓN LITERARIA (Las Palmas, 22-24 de mayo de 2008); "El arte de la forma breve: los microcuentos de Fernando Iwasaki”, de Marie-José Hanaï, y "Sobre Ajuar Funerario", de Efraín Cristal, trabajos presentados en el Coloquio Internacional "La nouvelle hispanoaméricaine contemporaine" (París, 25-26 de junio de 2008). Finalmente, destaco la aparición del artículo de José María Areta "Claves de Ajuar funerario" (2008).
} 
¿Qué significa tener miedo? La pregunta queda contestada en el significativo epígrafe de Lovecraft elegido por Iwasaki para encabezar Ajuar funerario: "La emoción más antigua y más intensa de la humanidad es el miedo, y el más antiguo y más intenso de los miedos es el miedo a lo desconocido" (Ajuar funerario: 9). Este sentimiento, asociado a términos como no familiar, ajeno, extraño, siniestro u ominoso -sinónimos del famoso unheimlich freudiano-, surge ante una experiencia que desestabiliza nuestra cotidianidad y nos hace sentir inseguros.

De ahí que se asocie frecuentemente a la fantasía -descrita por Todorov en su clásica Introducción a la literatura fantástica como "vacilación experimentada por un ser que no conoce sino las leyes naturales y se enfrenta, de pronto, con un acontecimiento de apariencia sobrenatural" (Todorov: 26)"- y al misterio, del que Cortázar apuntó acertadamente en "La muñeca rota" que "no se escribe con mayúscula como lo imaginan tantos narradores, sino que está siempre entre, intersticialmente" (Cortázar 1980: 260). Queda pues claro que, para conjurar el miedo, sólo queda una salida: buscar el orden y la protección, asociada en el caso de los niños a la familia y, en el de los adultos, a la estable y equilibrada realidad.

La literatura gótica, definida ya en 1968 por Mario Praz como "an anxiety with no possibility of escape" (Praz: 12), ${ }^{3}$ se muestra especialmente interesada por subrayar los procesos mentales de sus personajes. En sus mejores títulos crea espacios numinosos y secretos, en los que es posible experimentar tanto el terror (exterior y súbito) como el horror (interior y permanente), emociones entre las que se debate el lector en todo momento.

Entre el shock y el suspense, el texto de miedo debe construirse con la precisión de un mecanismo de relojería, apoyándose en una estructura in crescendo, una focalización insólita -a través de la que descubrimos nuevas posibilidades de lo real- y un escenario que, si bien en los primeros momentos se ubicó en parajes lejanos y exóticos, provoca tanto más miedo cuanto más cercano se muestra a nuestra realidad.

Como el propio Iwasaki señala, relatos de fantasmas han existido siempre: "Los hombres de todos los tiempos han sentido fascinación por el terror, aunque lo que ha variado es la distancia y la relación con el mismo; los atenienses que se aterraban con los mitos que describían la cólera de los dioses no pueden compararse con los ingleses que se reunían para divertirse contando historias de miedo; recordemos que el Frankenstein de Mary Shelley y El Vampiro de Polidori surgieron de una velada de fantasmas con Lord Byron" (Trazegnies 2004).

\footnotetext{
${ }^{3}$ Coincido con Anne Williams en su definición del gótico como un arte atemporal (Williams, 1995), aunque soy consciente de la importancia de los años finales del siglo XVIII en la acuñación del término y en la creación de una estética que ha sobrevivido hasta nuestros días.
} 
No está de más recordar que ya en el siglo I de nuestra era Plinio el Joven contaba en la carta vigésimo séptima del libro VII de sus epístolas la historia de una casa poseída por un fantasma, maldición que acabó cuando el filósofo Athenodoro descubrió que éste estaba enterrado en el patio sin las debidas honras fúnebres. Pero serán los maestros anglosajones quienes establezcan las bases del género. Así, Frederick Frank habla en The First Gothics: A Critical Guide to the English Gothic Novels, de nueve características tenidas muy en cuenta en Ajuar funerario:

1. Contención claustrofóbica.

2. Persecución subterránea.

3. Invasión sobrenatural.

4. Arquitectura y objetos de arte que cobran vida.

5. "Posiciones extraordinarias" y situaciones letales.

6. Ausencia de racionalidad.

7. Posible victoria del mal.

8. Artilugios sobrenaturales, artefactos, maquinaria y aparatos demoníacos.

9. Un constante devenir de interesantes pasiones (Frank 1987: 437).

Pasemos ahora a demoler un tópico tan extendido como peligroso: el del escaso valor de la literatura de terror en español. Si bien esta afirmación podría sostenerse -con brillantes excepciones- en relación a los siglos XVIII y XIX, resulta absolutamente alejada de la realidad en relación a nuestros días, como ha demostrado recientemente Jaume Pont en Brujas, demonios y fantasmas en la literatura fantástica hispánica (1999).

Cortázar ya atendió a este hecho en sus célebres "Notas sobre lo gótico en el Río de la Plata", donde subrayará la importancia del género de terror en su escritura ${ }^{4}$ y en la de otros autores conosureños. Sin embargo, puntualiza: "Pienso que recibimos la influencia gótica sin caer en la ingenuidad de imitarla exteriormente; en última instancia, ése es nuestro mejor homenaje a tantos viejos y queridos maestros" (Cortázar 1994: 87).

Iwasaki destaca asimismo este hecho incidiendo en la importancia de la tradición gótica hispánica y revelando sus lecturas de adolescencia:

Siempre han existido estupendos autores de literatura de horror en español, desde Bécquer hasta Borges, pasando por el peruano Clemente Palma, el uruguayo Quiroga o la española Pilar Pedraza (Trazegnies 2004).

${ }^{46 " L a}$ huella de escritores como Edgar Allan Poe -que prolonga genialmente lo gótico en plena mitad del siglo pasado- es innegable en el plano más hondo de muchos de mis relatos; creo que sin Ligeia, sin La caída de la casa Usher, no se hubiera dado en mí esa disponibilidad a lo fantástico que me asalta en los momentos más inesperados y que me lleva a escribir como única manera posible de atravesar ciertos límites, de instalarme en el terreno de lo otro" (Cortázar 1994: 82-83). 
Sobre los doce descubrí a Poe y Lovecraft, de quienes recuerdo el desasosiego que me produjeron «La caída de la casa Usher» y «Los perros tíndalos», respectivamente. Cuando tenía catorce o quince años, quien me deslumbró de manera fulminante fue Julio Cortázar con «Casa tomada» (...) Ya en la universidad -con dieciséis años- leí «El espejo y la máscara» y los demás cuentos de El libro de arena de Borges. Desde entonces he leído muchísimos cuentos maravillosos, aunque ya ninguno me ha desvelado y conmovido tanto como los que he tratado de recordar aquí (Muñoz 2007). ${ }^{5}$

En los años ochenta del pasado siglo se produjo una revitalización internacional del género con la aparición de tribus urbanas que se autodenominaron nuevos románticos, neogóticos o siniestros. Con sus indumentarias oscuras, su fascinación por ciertos conjuntos musicales y films satánicos y con un nivel cultural muy superior al de otros grupos juveniles, estos chicos hicieron proliferar muy pronto en la red -otra de sus pasiones confesas- las páginas dedicadas al terror.

Todo ello explicaría la aparición en las literaturas hispánicas de los últimos treinta años de novelas, cuentos y antologías tan interesantes como Las joyas de la serpiente (1984), Necrópolis (1985), Mater Tenebrarum (1987), Arcano 13, cuentos crueles (2000) у Fantástico interior : antología de relatos sobre muebles y aposentos (2001), de Pilar Pedraza; Mejor desaparece (1987) y Antes (1989), de Carmen Boullosa; El mal menor (1996), de Charlie Feiling (sin duda una de los mejores novelas de las últimas décadas); Técnicamente humanos (1996), Invenciones enfermas (1997) y Registro de Imposibles (2000), de Cecilia Eudave; Ciudad espejo, ciudad niebla (1997), Sombras sin tiempo (1999) y Aquí y en el más allá (2005), de Gerardo Horacio Porcayo; Inquieta compañía (2004), de Carlos Fuentes (quien ya iniciara su trayectoria literaria con extraordinarios cuentos fantásticos); El huésped (2006) de Guadalupe Nettel, o Cuentos de la abadía de Carfax. Historias contemporáneas de horror y fantasía (2006), de Nomi Pendzik. ${ }^{6}$

\section{MINIFICCIÓN Y ESCALOFRÍO}

La escritora argentina Ana María Shua, maestra indiscutible en el manejo de la brevedad y autora del texto escogido para iniciar la presente reflexión, señala en su introducción a Temporada de fantasmas un hecho incuestionable "Las minificciones tienden

\footnotetext{
${ }^{5}$ Su fascinación por Poe lo llevó a escribir "Noche de brujas en Baltimore” (Iwasaki 1998: 56-58), así como a preparar junto a Jorge Volpi la edición de los cuentos completos del norteamericano, que verá la luz en 2009.

${ }^{6}$ Las escritoras, que han hecho correr ríos de tinta por su especial afición al género, siguen teniendo una gran importancia en el mismo por su capacidad para reflejar tanto el desamparo como complejos procesos psicológicos en sus personajes.
} 
en su mayor parte al género fantástico, en parte porque se les exige provocar algún tipo de sorpresa estética, temática o de contenido, ya que el sutil desarrollo de climas o personajes son casi imposibles" (Shua 2004: 8).

Así se explica la importancia de lo sobrenatural en Cuentos breves y extraordinarios (1957) de Jorge Luis Borges y Adolfo Bioy Casares, y en El libro de la Imaginación (1976) de Edmundo Valadés, antologías que sirvieron de piedra de toque para potenciar la práctica de y la atención sobre el género, y que han sido continuadas en títulos recientes como Grandes minicuentos fantásticos (2004), de Benito Arias.

Y es que el escalofrío siempre ha estado en la base de los mejores microrrelatos, sea con toques humorísticos -como en "Aquella muerta", de Ramón Gómez de la Serna (1935)- ${ }^{7}$ o para producir un súbito desasosiego. Así se aprecia en el clásico "Sola y su alma", de Thomas Bailey Aldrich, compilado por Borges, Bioy Casares y Ocampo en su clásica Antología de literatura fantástica (1940) y uno de los títulos más glosados en la historia de la literatura: "Una mujer está sentada sola en una casa. Sabe que no hay nadie más en el mundo: todos los otros seres han muerto. Golpean a la puerta" (Borges 1989: 36).

En el mundo hispánico destaca en este sentido Los niños tontos (1956), de Ana María Matute, donde la crueldad infantil es presentada en toda su crudeza. Así ocurre, por ejemplo, en "El niño que no sabía jugar":

Había un niño que no sabía jugar. La madre le miraba desde la ventana ir y venir por los caminillos de tierra, con las manos quietas, como caídas a los dos lados del cuerpo. Al niño, los juguetes de colores chillones, la pelota, tan redonda, y los camiones, con sus ruedecillas, no le gustaban. Los miraba, los tocaba y luego se iba al jardín, a la tierra sin techo, con sus manitas, pálidas y no muy limpias, pendientes junto al cuerpo como dos extrañas campanillas mudas. La madre miraba inquieta al niño, que iba y venia con una sombra ante los ojos. "Si al niño le gustara jugar yo no tendría frío mirándole ir y venir". Pero el padre decía, con alegría: "No sabe jugar, no es un niño corriente. Es un niño que piensa".

Un día la madre se abrigó y siguió al niño, bajo la lluvia, escondiéndose entre los árboles. Cuando el niño llegó al borde del estanque, se agachó, buscó grillitos, gusanos, crías de rana y lombrices. Iba metiéndolos en una caja. Luego, se sentó en el suelo, y uno a uno los sacaba. Con sus uñitas sucias, casi negras, hacia un leve ruidito: ¡Crac!, y les segaba la cabeza (Matute 1994: 47).

La indiferencia con que enfrentan el dolor o la muerte ajena personajes pretendidamente inocentes se encuentra, asimismo, en la base de los microrrelatos reunidos por la chilena Pía Barros en la serie "Ropa usada", de la que ofrecemos un ejemplo:

\footnotetext{
7 -Aquella muerta me dijo:

- ¿No me conoces?... Pues me debías conocer.

Has besado mi pelo en la trenza postiza de la otra (Arias, 91).
} 
Ropa usada I.

(A Ana Madre)

Un hombre entra a la tienda. La chaqueta de cuero, gastada, sucia, atrapa su mirada de inmediato. La dependienta musita un precio ridículo, como si quisiera regalársela. Sólo porque tiene un orificio justo en el corazón. Sólo porque tras el cuero, el chiporro blanco tiene una mancha rojiza que ningún detergente ha podido sacar. El hombre sale feliz a la calle.

A pocos pasos, unos enmascarados disparan desde un callejón. Una bala hace un giro en ciento ochenta grados de su destino original. Se diría que la bala tiene memoria. Se desvía y avanza, gozosa, hasta la chaqueta. Ingresa, conocedora, en el orificio. El hombre congela la sonrisa ante el impacto.

La dependienta, corre a desvestirlo y a colgar nuevamente la chaqueta en el perchero.

Lima sus uñas distraída, aguardando (Barros 2000: 13).

Del mismo modo, Espido Freire juega a subvertir el orden establecido en sus brevísimos Cuentos malvados. En ellos los ángeles pueden ser vampiros o las sirenas olvidar su labor samaritana, como se aprecia en esta malsana y divertida recreación de "La sirenita": "Medio ahogado, vio cómo una sirena nadaba hacia él y tendió sus manos hacia ella. La sirena no se acercó más. Con su hermoso rostro sereno contempló cómo el príncipe se hundía lentamente. Cuando dejó de respirar, ella se aburrió, y abandonó el lugar envuelta en un remolino de espuma" (Freire 2003: 27).

En otro orden de cosas, el maestro Cortázar demostró que era posible atrapar el tono gótico en una página -"Instrucciones-ejemplos sobre la forma de tener miedo" y "Propiedades de un sillón", incluidos en Historias de cronopios y de famas (1962), y descubrió las múltiples posibilidades de la focalización y el lenguaje telegráfico en "Cortísimo metraje":

Automovilista en vacaciones recorre las montañas del centro de Francia, se aburre lejos de la ciudad y de la vida nocturna. Muchacha le hace el gesto usual del auto-stop, tímidamente pregunta si dirección Beaune o Tournus. En la carretera unas palabras, hermoso perfil moreno que pocas veces pleno rostro, lacónicamente a las preguntas del que ahora, mirando los muslos desnudos contra el asiento rojo. Al término de un viraje el auto sale de la carretera y se pierde en lo más espeso. De reojo sintiendo cómo cruza las manos sobre la minifalda mientras el terror poco a poco. Bajo los árboles una profunda gruta vegetal donde se podrá, salta del auto, la otra portezuela y brutalmente por los hombros. La muchacha lo mira como si no, se deja bajar del auto sabiendo que en la soledad del bosque. Cuando la mano por la cintura para arrastrarla entre los árboles, pistola del bolso y a la sien. Después billetera, verifica bien llena, de paso roba el auto que abandonará algunos kilómetros más lejos sin dejar la menor impresión digital porque en ese oficio no hay que descuidarse (Cortázar 1980: 136). ${ }^{8}$

\footnotetext{
${ }^{8}$ Esta interesante línea de trabajo es seguida por Luis Mateo Díez en el memorable "El sueño": "Soñé que un niño me comía. Desperté sobresaltado. Mi madre me estaba lamiendo. El rabo todavía me tembló durante un rato" (Díez 2002: 135).
} 
Basten estos ejemplos para dejar constancia de que el escalofrío goza de buena salud en el microrrelato hispánico. Concluyo así este breve repaso destacando la importancia de las pesadillas en tres textos recientemente publicados: Cuentos del libro de la noche (2005), de José María Merino -impagables en este sentido sus minificciones “Ojos" y "Huellas"-; Horrores cotidianos (2007), de David Roas - mucho más cercano al espíritu del absurdo que al del terror; y, finalmente, Miedo me da (2007), de José Antonio Francés, estrechamente vinculado a los temas y técnicas del taller Iwasaki.

\section{AJUAR FUNERARIO O CÓMO LOGRAR SONRISAS ESTREMECIDAS}

\section{Paratexto y claves genéricas}

Desde su título, Ajuar funerario conjuga el homenaje a la literatura gótica con el recuerdo de ciertas tradiciones peruanas, aproximando lo cotidiano a lo sepulcral en una apuesta por confundir ámbitos tradicionalmente separados. Como el mismo autor explica con su habitual ironía: "Los antiguos peruanos creían que en el otro mundo sus seres queridos echarían en falta los últimos adelantos de la vida precolombina, y por ello les enterraban en gruesos fardos que contenían vestidos, alimentos, vajillas, joyas, mantones y algún garrote, por si acaso. Los arqueólogos, esos aguafiestas del eterno descanso, bautizaron como ajuar funerario aquel melancólico menaje" (Ajuar funerario: 11).

Tras una portada muy en consonancia con el espíritu macabramente lúdico de la obra, en la que se representa un grotesco cadáver dentro del ataúd y ataviado con sus mejores galas, se establece un claro paralelismo entre los objetos materiales del ajuar y los textuales que integran el volumen: "Las historias que siguen a continuación quieren tener la brevedad de un escalofrío y la iniquidad de una gema perversa. Perlas turbias, malignos anillos, arras emputecidas..., un ajuar funerario de negras y lóbregas bagatelas que brillan oscuras sobre los desechos que roen los gusanos de la imaginación" (Ajuar funerario: 12).

Los epígrafes que encabezan la obra, pertenecientes a Lovecraft, Poe y Borges, descubren la filiación gótica del libro, mientras la dedicatoria humorística -“A Marle, que está de miedo" (Ajuar funerario: 7)- y la línea que inicia la serie de microrrelatos -“"Y ahora, abra la boca': El dentista" (Ajuar funerario: 10)- revelan la comodidad con la que Iwasaki pasa de un registro culto a otro cercano al plano doméstico. ${ }^{9}$

\footnotetext{
${ }^{9}$ Marle es la esposa de Iwasaki, a la que éste dedica todas sus obras y que hace justo honor a la dedicatoria, mientras el miedo al dentista resulta una de las principales fobias del escritor, en la base de la novela Neguijón y de "La silla eléctrica" (Ajuar funerario: 56), pesadilla de ejecución resuelta finalmente como rutinaria visita al odontólogo.
} 
Ya en su presentación en la Feria del Libro de Madrid, Ajuar funerario fue definido por Antonio Muñoz Molina como "libro excelente, original, muy divertido y escalofriante de leer". Configurado como un conjunto de pesadillas contadas con enorme laconismo, se inscribe tanto en la tradición del relato de horror como en la de de la brevedad lo que, como sostiene su autor para demostrar una vez más su alergia a las clasificaciones, le viene más del interés por los haikus -debido a su sangre medio japonesa- que a la propia tradición del microrrelato (Tellería). Este hecho no impide que, al contestar un cuestionario en el blog Diario sin nombre, demuestre su respeto e interés por el género: "Cuando he escrito un microrrelato sé que me he comprometido igual que cuando he escrito una novela. Por lo tanto, no creo que los escritores los percibamos como algo menor. Lo que pasa es que todavía ninguna top-model ha declarado que flipe con los microrrelatos, pero en cuanto Hipólito G. Navarro acabe el de templarios que está escribiendo, todo va a cambiar" ("Fernando Iwasaki en pocas palabras"). ${ }^{10}$

Así, confiesa la difícil ejecución del género a Tellería: "Terminar Ajuar Funerario me llevó más de cinco años de escritura, pero por razones estrictamente operativas, ya que los microrrelatos hay que escribirlos una vez a las quinientas. Al ser un libro de microcuentos de terror, siempre estuve a la caza de historias, sueños, pesadillas y obsesiones, que anotaba en una libreta y más tarde transcribía en la computadora" (Tellería).

Por otra parte, descubre la estrecha relación existente entre microrrelato, terror y oralidad $^{11}$ en diferentes entrevistas:

Creo que el microrrelato supone primero la oralidad, un contador de historias. El escritor interviene al final para miniar, limar y pulir esas miniaturas orales. Estos son mis primeros microrrelatos, pero no son mis primeras historias orales (García).

Ajuar funerario es un homenaje a la literatura de terror tanto oral como escrita, pues mi libro le debe tanto a Lovecraft como a la Casa Matusita (...) Tengo que admitir que he reciclado leyendas urbanas e historias que me han contado algunos ateridos informantes (Trazegnies). ${ }^{12}$

Con este libro ha tratado de darle dignidad literaria a una serie de historias que escuché desde niño y que me desvelaron durante años; (...) Elegí el terror porque

\footnotetext{
${ }^{10}$ En el año 2005 publicó en Lima un texto que da idea desde su título de su interés por el género: Cuentos pigmeos. Antología de la minificción latinoamericana.

${ }^{11}$ Destacada por críticos como Jackson y Hoffman en sus conocidos trabajos Fantasy: The Literature of Subversion (1981) y "The Fantastic in Fiction: Its Reality Status, Its Historical Development and its Transformation in Postmodern Narration" (1982).

${ }^{12}$ La limeña Casa Matusita, que probablemente se encuentre en el origen del microrrelato "La casa embrujada" (Ajuar funerario: 68-69), tuvo como primera propietaria a Parvaneh Dervaspa, condenada por bruja en 1753. Desde entonces ha alimentado una historia de destrucción y muerte, según la cual allí vivió un hombre asesinado por sus sirvientes, perdió la razón un sacerdote e incluso afectó al conocido Humberto Vílchez Vera. Fue una de las más conocidas leyendas de la Lima de los ochenta, por lo que Iwasaki se vería indefectiblemente tocado por su halo maldito.
} 
quería darle dignidad a esa tradición de historia oral que tenemos en América latina y que en la literatura americana siempre había estado en segundo plano (Chiappe).

Poe está muy bien, pero en español, desde Bécquer hasta Borges, pasando por Horacio Quiroga o el peruano Clemente Palma, existe también una importante tradición de literatura de horror que es muy devota de la oralidad, de esas típicas historias que se cuentan y mi libro se nutre de estas historias orales (J.A.).

La relación con la oralidad no acaba aquí. Como de nuevo señala a Chiappe, "el libro surge de estas historias que yo he ido escuchando desde pequeño en casa y en la calle y que fui escribiendo precisamente para leerlas a los alumnos en esas charlas organizadas por el Centro Andaluz de las Letras" (Chiappe). Este público adolescente, especialmente aficionado a las historias de terror, agradeció sin duda la intuición de Iwasaki: "Pensé que para ellos, los chavales, sería más fácil aficionarles a la lectura con esos pequeños relatos salidos de la imaginación y de esas historias que uno ha escuchado que dando alguna clase teórica" (J.A). De ahí la presencia de historias tan conocidas como las de la autoestopista fantasma que, señala, "se repite con distintas variantes en cada país" (Chiappe).

El volumen descubre asimismo el interés de su autor por la colección de textos integrados -ya presente en títulos como Inquisiciones peruanas, Helarte de amar o El libro de mal amor- y por la experimentación con diversos géneros. Aficionado a cuentarlo todo ${ }^{13}$, Iwasaki recurre a las leyendas urbanas -"El pasajero", las tres versiones de "La chica del auto stop"-, el documento inquisitorial -“Animus, finibus"-, las parábolas -“Bienaventurados los pobres de espíritu", "Del apócrifo Evangelio de san Pedro (IV, 1-3)"-, las entradas de diccionario -"Del Diccionario Infernal del padre Plancy"-, las reseñas -“El libro prohibido”-, los testimonios pseudo-históricos -“Kruszwicy, 834 D.C.” y, sobre todo, a la narración de pesadillas a lo largo de todo el volumen-.

En cuanto a su motivación para acercarse a la brevedad, es tan clara -“Asumo el riesgo de experimentar; por eso estos microrrelatos" (Chiappe)- como resultó compleja la génesis del volumen:

El título y el prólogo sí son del año 98, cuando Lengua de Trapo me solicitó un cuento de diez páginas para la antología Líneas Aéreas y se me ocurrió mandar diez de aquellas miniaturas siniestras. Los diez microrrelatos que aparecieron en Líneas Aéreas comenzaron a circular por Internet de una manera sorprendente, y cuando Andrés Neuman me pidió cuentos inéditos para Pequeñas resistencias y le pasé

${ }^{13}$ Rasgo clave de su poética, confesado en "Mi primera experiencia textual": "Uno está persuadido de que las poéticas y los manifiestos sólo sirven para que filólogos y concejales se cuelen de matute donde no les llaman, y así prefiero ser poéticamente correcto y amenazar con cuentarlo todo. Es decir, cuentar columnas, cuentar ensayos, cuentar artículos, cuentar pregones, cuentar prólogos, cuentar presentaciones y -por supuestocuentar novelas" (Iwasaki 2006: 81). Este hecho resulta de nuevo apreciable en Cuando dejamos de ser realistas, su más reciente publicación, que ha recibido el premio Algaba de Ensayo 2008. 
algunos inéditos de Ajuar funerario, me exhortó a publicarlos sin demora. Doy fe que Juan Casamayor no se corrió (García).

Más adelante insiste en este hecho -"Las primeras imágenes me vinieron a la mente a comienzos de los noventa, después de advertir que en muy pocas líneas era posible producir desasosiego y escalofrío" (García) ${ }^{14}$-, y descubre la diferencia entre la concepción de Ajuar funerario y otras obras: "[Iwasaki] reconoce que para enfrentarse a textos de aliento más largo no toma notas, pues no cree que las novelas se construyan con fogonazos ni compilando chispazos" (Chiappe).

Por último, destaca las claves de su escritura -"Un microrrelato de terror no puede aspirar al misterio y la creación de atmósferas, sino a provocar sensaciones fulminantes como el escalofrío, la náusea o el sobresalto" (Trazegnies)-, atendiendo a que los textos sean necesariamente narrativos -"El género de terror me obligaba a poner una distancia con los aforismos y los poemas en prosa, géneros que algunas veces pasan por minificción" (Trazegnies)- y al placer que le provocó este nuevo experimento: "fue un ejercicio muy exigente, pero al mismo tiempo bastante divertido" (Trazegnies).

\section{El autor en la obra}

En Ajuar funerario aparecen reflejadas las principales obsesiones literarias de Iwasaki. Ya Tres noches de corbata (1987), su primera publicación, presentaba una fantasía gótica en la portada -con búho y casa negra incluidos-, descubriendo el interés de su autor por las múltiples apariencias de lo real, los sueños, las pesadillas y la magia. Así se aprecia en cuentos como "El ritual" y "Tres noches de corbata", cuyos argumentos se ven repetidos con algunas variaciones en "Ya no quiero a mi hermano" (Ajuar funerario: 30) y "La muchacha nueva" (Ajuar funerario: 54-55). Igualmente, los relatos de A Troya, Helena (1993) "Pesadilla en Chacarilla" y "Erde" encuentran una nueva versión en "Cosas que se mueven solas" (Ajuar funerario: 112) y “Gorgona” (Ajuar funerario: 66).

Por su parte, el mundo contrarreformista y pícaro de confesores, anales eclesiásticos y beatas retratado en Inquisiciones peruanas (1994) y Neguijón (2005) encuentra una nueva versión en "Animus, finibus" (Ajuar funerario: 20) y "Los visitantes" (Ajuar funerario: 38).

\footnotetext{
${ }^{14}$ Iwasaki parece hacerse eco de la idea de que al terror le va bien la brevedad y de que la economía de palabras supone un disparador del miedo, hecho demostrado por novelistas como Dickens o Hawthorne, que escogieron la narración breve como vehículo para sus cuentos de de miedo. Si Julia Briggs señala que "a horror that is effective for thirty pages can seldom be sustained for three hundred" (Briggs: 13), podríamos reducir la cantidad de páginas a una en el caso de las minificciones objeto del presente análisis.
} 
Uno de los aspectos más interesantes de Ajuar funerario viene dado por su extraordinaria utilización de la perspectiva infantil a la hora de narrar las pesadillas. Los mejores textos se encuentran protagonizados por niños desamparados, que sienten el abandono de aquellos en quienes confiaban y que debieron protegerlos. Y es que, como señala Víctor Bravo, "si el miedo se encuentra en la raíz de la condición humana, lo es porque el primer reconocimiento de toda conciencia es el desamparo" (Bravo: 13).

Ya lo señalaba Cortázar en "Lo gótico en el Río de la Plata": "Salvo que una educación implacable se le cruce en el camino, todo niño es en principio gótico" (Cortázar 1994: 83). ${ }^{15}$ Iwasaki insiste en este hecho en numerosas entrevistas:

En cuanto a los niños, estoy persuadido de que la literatura de terror supone la infancia, pues si no hubiéramos sido niños sólo le tendríamos miedo a Hacienda y a los dentistas. Por lo tanto, la infancia nos preparó para ser aprensivos a la oscuridad, lo desconocido, la muerte, la soledad, lo sobrenatural, las pesadillas y sobre todo a las viejas, cuando están majaras y despeinadas (Muñoz).

En otras historias he querido crear la sensación de desasosiego, sobre todo en las protagonizadas por niños (...) La literatura de horror se nutre de los miedos infantiles, de los niños que fuimos o del que tenemos dentro (Chiappe).

La infancia es la edad de todos los terrores primordiales y el niño siempre es sujeto de terror. O el niño que fuimos o los niños que engendramos. "Peter Pan" y "La cueva" tienen como elemento común esa infancia terrorífica o aterradora, y me interesa explorar esos territorios. La literatura de terror nace de las pesadillas completas de un niño en coma (García).

El sentimiento de desamparo se hace especialmente patente en microrrelatos como "La cueva", donde un niño se pierde mientras juega con sus hermanas bajo la colcha de la cama paterna: “QQué grande era la cama de mis papás! Una vez cogí la linterna de la mesa de noche y les dije a mis hermanas que me iba a explorar el fondo de la cueva. Al principio se reían, después se pusieron nerviosas y terminaron llamándome a gritos. (...) La cueva era enorme y cuando se gastaron las pilas ya fue imposible volver" (Ajuar funerario: 23)

Pero los niños asustan más cuando se convierten en victimarios. Es el caso de la niña caníbal a la fuerza en "Las manos de la fundadora": "ellas creen que vomité de susto, pero tenía que impedir que me pegara. La mano izquierda sabía mejor" (Ajuar funerario: 97). Esta conducta feroz, similar a la de Los niños tontos de Matute, se repite en el chico que pega la hostia en el álbum de Primera Comunión, en los niños brujos de "Dulce compañía” y "La

\footnotetext{
${ }^{15}$ Este hecho ha sido asimismo destacado por David Punter en The Romantic Unconscious. A Study in Narcissism and Patriarchy, donde el autor sigue las aportaciones realizadas en la temprana fecha de 1932 por la psicoanalista Melanie Klein en The Psychoanalisis of Children (Punter 1990).
} 
muchacha nueva", el vampiro infantil de "El balberito" y el terrorífico protagonista de "Hambre".

Resulta así evidente que el terror se encuentra estrechamente asociado a los recuerdos de infancia de Iwasaki ${ }^{16}$, quien ha revelado incluso el origen real de "Tres noches de corbata" y "La muchacha nueva":

[Iwasaki] recuerda que nunca ha experimentado más miedo que cuando se marchaban sus padres y se quedaban al cuidado de Josefina, que tenía 14 años. «Era tan niña como nosotros, recuerda, pero nos transmitía unos cuentos terribles, alucinantes. El mundo del niño lo absorbe todo... Si fuéramos adultos desde el momento de nacer, sólo tendríamos miedo a Hacienda (Echeverría).

Si en "Tres noches de corbata" la criada se convierte al final en el personaje de su propio cuento -el demonio "Chullachaqui", que mata a los niños-, en "La muchacha nueva" son los chicos quienes "hacen desaparecer" a sus sucesivas cuidadoras gracias a su pacto con el diablo. ${ }^{17}$

En otro orden de cosas, la mitología producida por los modernos medios de comunicación -cine, literatura, música popular, televisión- es utilizada con profusión en Ajuar funerario, hecho que nos remite a otros títulos de su autor como El descubrimiento de España (1996), La caja de pan duro (2000), Libro de mal amor (2001) o Helarte de amar (2006).

Así lo señala el mismo Iwasaki a Chiappe, a quien confiesa que "también le han influido las películas de cine y las series de televisión, como La familia Adams o Los Monsters", y así se aprecia en "Peter Pan", uno de los pocos microrrelatos realistas del conjunto en el que el despiadado protagonista, decepcionado porque cree ver en los padres de sus amigos al Hombre Lobo, Batman o Tarzán, inventa una naturaleza heroica para su progenitor: "Entonces corrí a la cocina y saqué el hacha de cortar la carne. Por la ventana entraban la luz de la luna y los aullidos del papá de Mendoza, pero mi padre ya grita más

16 “Cuando era niño, la madre de Fernando Iwasaki le repetía que había que tenerle más miedo a los vivos que a los muertos, porque los muertos le ayudaban: las ánimas del purgatorio, los espíritus de seres queridos, los santos; todos echaban una mano en caso de necesidad. Desde entonces, Iwasaki tuvo la impresión de estar rodeado de muertos que veían lo que él hacía a todas horas. Ese miedo y otras angustias, como el terror infantil al fallecimiento de los padres, le rondaron como fantasmas hasta que comenzó a apuntarlos como si se trataran de pequeñas historias terroríficas" (Chiappe).

${ }^{17}$ El tema de la criada que se venga de sus señores a través de la magia es abordado por Carlos Fuentes en "La gata de mi madre", donde la indígena Guadalupe acaba con su vieja y despótica ama por ser la reencarnación de una bruja sacrificada siglos atrás (Fuentes: 36-47). . 
fuerte y parece un pirata de verdad. Que se cuiden Merino, Salazar y Gómez, porque ahora soy el hijo del Capitán Garfio" (Ajuar funerario: 28). ${ }^{18}$

Otras aficiones de Iwasaki forman parte del libro. Es el caso de los Beatles -“A Mail in the Life" remite a "A Day in the Life", penúltima canción del lado B del Sergeant Pepper's Lonely Hearts Club-, también homenajeados en el cuento de A Troya, Helena "Rock in the Andes", dedicado a John Lennon; en el Libro de mal amor -con un epígrafe tomado de la canción I Will-, y en Helarte de amar, que contiene dos relatos donde las canciones del grupo británico propician las aventuras eróticas.

Por su parte, la bibliofilia del autor es puesta de manifiesto en "El bibliófilo" (Ajuar funerario: 39-40) y "Los yernos" (Ajuar funerario: 83-84) -títulos que revelan el profundo temor a perder sus libros de todo poseedor de una buena biblioteca-, y en "El libro prohibido" (Ajuar funerario: 35-36), del que señala: “¿Qué puedo decir de los bibliófilos, libreros y bibliotecarios en general? En uno de los microrrelatos de Ajuar funerario sugiero que el «libro de arena» era en realidad el apócrifo Necronomicón. No encontré mejor homenaje al libro como «arte facto» de terror" (Muñoz).

La formación humanística de Iwasaki, que consiguió el grado de bachiller con la tesis Simbolismos religiosos en la metalurgia prehispánica (1983), impartió clases en la universidad sobre religiones comparadas y escribió eruditos artículos en torno al tema, refleja un interés por libros prohibidos, ritos secretos y exorcismos que lo llevó, por ejemplo, a ser el introductor en Sevilla de monseñor Corrado Balducci, el exorcista del Vaticano. ${ }^{19}$

Así se aprecia el argumento de "El antropólogo" (Ajuar funerario: 71) y la mención a libros como El diccionario infernal del Padre Plancy en el casi homónimo microrrelato (Ajuar funerario: 119), divertido homenaje a la tradición alemana del Schauerroman -donde

\footnotetext{
${ }^{18}$ La mezcla de crueldad e inocencia del narrador recuerda la de los chicos oligofrénicos en "La gallina degollada" de Horacio Quiroga, cuento publicado en Cuentos de amor, de locura y de muerte (1917) e inolvidable en su escena final, cuando la hermana pequeña aparece muerta a manos de quienes la creyeron "una gallina". Así ocurre también con el protagonista de "27 de abril”, microrrelato incluido por Edmundo Paz Soldán en Las máscaras de la nada (1990):

Era el cumpleaños de Pablo Andrés y decidí obsequiarle la cabeza de Daniel, perfumada y envuelta con elegancia en lustroso papel café. Supuse que le agradaría porque, como casi todo buen hermano menor, odiaba a Daniel y no suportaba ni sus ínfulas ni sus cotidianos reproches.

Sin embargo, apenas tuvo entre sus manos mi regalo, Pablo Andrés se sobresaltó, comenzó a temblar y a sollozar preso de un ataque de histeria. La fiesta se suspendió, los invitados nos quedamos sin probar la torta, alguien dijo son cosas de niños, y yo pasé la tarde encerrado en mi dormitorio, castigado y sintiéndome incomprendido" (Paz Soldán: 25).

${ }^{19} \mathrm{El}$ autor contestó con su habitual ironía a la pregunta de si esta relación le había ayudado a escribir el volumen que comentamos: "A sus 83 años Balducci es la máxima autoridad de la Iglesia en demonología, pero también un gran conocedor del rock; la mayor parte del tiempo que estuvo en Sevilla hablamos de rock y más bien poco de Satanás, que según Balducci es un pobre diablo, lo que me hizo pensar que el demonio está más cerca de 'El día de la Bestia' que de 'La Profecía'" (Trazegnies).
} 
eran frecuentes las relaciones sexuales con demonios- que convierte al diabólico Gomory en una call girl con tarifa estipulada por minuto de conversación.

La alusión a la hot line da pie para comentar otro rasgo profundamente novedoso de Ajuar funerario: su utilización de las nuevas tecnologías de comunicación -vídeos, mensajes SMS, correos electrónicos, chats- para provocar en miedo, situándose en la línea de films japoneses de culto como The Call (2000) o The Ring (2002). Si algunos de las microrrelatos aluden a los métodos tradicionales de comunicación con los espíritus -"La ouija", "Ya no quiero a mi hermano", "Última voluntad", la actualización del género queda clara en títulos como "666" 20 y, especialmente, en "El dominio", donde el creador de la URL www.infierno.com descubre, tras hacerse rico con su invento, que éste le ha hecho esclavo del diablo. $^{21}$

\section{TERRORES DEL AJUAR}

Llego así a la última parte de mi exposición, en la que destacaré los temores presentes en Ajuar funerario atendiendo a cuatro aspectos fundamentales: la claustrofobia, el miedo al abandono, al castigo y a la pérdida de identidad.

$* * *$

\section{CLAUSTROFOBIA}

En el siglo XIX, las localizaciones características de la primera época de la literatura gótica -castillos y conventos del sur de Europa- fueron sustituidas por espacios mucho más cercanos a los lectores -de clase media- que devoraban estos textos: casas repletas de salones, sótanos y áticos por explorar. Este hecho explica que uno de los temas más tratados por Iwasaki en Ajuar funerario sea el del espacio hostil, presente en "W.C" -demostración fehaciente de la originalidad del autor, que sitúa el encuentro con el monstruo en el retrete de una gasolinera- y, en un tono mucho más respetuoso con la tradición, en "La habitación maldita", "La casa embrujada", "No hay como el baño de casa", "La casa de muñecas", "Hay que bendecir la casa" o "Cosas que se mueven solas".

\footnotetext{
${ }^{20}$ El narrador recibe la sobrecogedora llamada a su móvil de un conocido muerto, que acaba con el siguiente comentario: "En la pantalla parpadeaba un número inverosímil. No me he atrevido a coger el teléfono, pero ha dejado un mensaje en el buzón de voz" (Ajuar funerario: 90).

${ }^{21}$ José Antonio Francés, que inicia Miedo me da precisamente con un epígrafe de Iwasaki, asume asimismo esta veta creativa en "Canal 666", "Perdida" -el narrador llora ante la tumba de su hermana y de repente le llega una llamada perdida desde la lápida- o "Envía alma" -un chico recibe la fecha de su muerte a través del juego de la página web www.estasmuerto.com, y para alargar su vida debe enviar continuamente SMS al número estipulado.
} 
Ya Chris Baldick señaló la naturaleza claustrofóbica de los espacios que provocan miedo: "Gothic texts comprise a fearful sense of inheritance in time with a claustrophobic sense of enclosure in space, these two dimensions reinforcing one another to produce an impression of sickening descent into disintegration. The Gothic text often flourishes in spaces that imprison or restrict efforts to move or exist comfortably and the combination of both circumstances creates the feeling of disintegration or fragmentation”. (Baldick: XIII). Iwasaki, buen conocedor de esta tradición, logra retratar en unas cuantas pinceladas el terror que desprenden estos lugares. Así ocurre en "La habitación maldita” -"Las paredes estaban llenas de crucifijos y los espejos apenas reflejaban mis movimientos. Recién cuando me eché en la cama reparé en la pintura del techo: un Cristo viejo y enfermo que me miraba sobrecogido. Me dormí con la inexplicable sensación de sentirme amortajado" (Ajuar funerario: 14)-; en "La casa embrujada" - "la casa no tenía espejos y a todos los personajes de las pinturas les habían borrado los ojos. Los relojes marcaban a destiempo la misma hora" (Ajuar funerario: 68)- o, finalmente, en "El salón antiguo" -"todo oscuro, todo grande, (...). En uno hay una señora que te mira molesta, en otro se ve a una niña que parece un fantasma y encima hay un Cristo que da miedo" (Ajuar funerario: 76). Evidentemente, todos estos lugares poseen un rasgo común: quienes los han hollado nunca lograrán salir -habitación, tumba y cama se hacen sinónimos-, remitiendo así a una de las fobias más generalizadas entre los seres humanos: la tapefobia o miedo a ser enterrado vivo, reflejada asimismo en otros títulos como "Réquiem por el ave madrugadora" y "El milagro maldito". 22

\section{FAMILIAS PERVERSAS: EL MIEDO AL ABANDONO Y AL CASTIGO.}

El de sobras conocido el papel que puede jugar la familia como elemento provocador de ansiedad en nuestras vidas. De hecho, William Day va mucho más allá, sosteniendo que la emoción central del gótico es el miedo, y "the source of that fear is anxiety and terror over the experiences of the family" (Day: 5).

${ }^{22}$ Felipe Benítez ha escrito uno de los mejores microrrelatos sobre el tema:

Que griten. Yo, como si fuese sordo. Que arañen sus elegantes forros de seda. A mí sólo me pagan para que vigile esto, no para que cuide de ellos ni para que me quiten el sueño con sus gritos. ¿Que bebo demasiado? No sé qué harían ustedes en mi lugar. Aquí las noches son muy largas... Digo yo que deberían tener más cuidado con ellos, no traerlos aquí para que luego estén todo el tiempo gritando, como lobos, créanme. Ahora bien, que griten. Yo, como su fuese sordo. Pero si a alguno se le ocurre aparecer por aquí, lo desbarato y lo mando al infierno de una vez, para que le grite al Demonio... Pero a mí que me dejen. Toda la noche, como les digo. Y tengo que beber para coger el sueño, ya me dirán. Si ellos están sufriendo, si están desesperados, que se aguanten un poco, ¿verdad? Nadie es feliz. Además, lo que les decía: tengan ustedes más cuidado. Porque luego me caen a mí, y ustedes no me pagan para eso, sino para cuidar los jardines y para ahuyentar a los gamberros, ¿no? ¿Qué culpa tengo yo de que los entierren vivos? Y claro, ellos gritan (Benítez 1994: 79). 
Como ya hemos señalado, la mayoría de los relatos de Ajuar funerario cuentan con protagonistas infantiles, que temen a partes iguales el abandono y el castigo de quienes deben protegerlos. La casa y la escuela se convierten, así, en espacios donde experimentan una enorme soledad, siempre a la espera de la recriminación o el azote por parte de madres, abuelas y monjas, Así ocurre con la progenitora en "Juicio final”, convertida en un verdadero “ángel vengador" (Ajuar funerario: 98), o con la monstruosa protagonista de "Abuelita está en el cielo", presentada por la madre del narrador "rodeada de ángeles y santos", pero cuya verdadera identidad es reflejada por el chico al final del cuento: "viene de noche a mi cuarto, llorando y toda despeinada, arrastrando a un bebito encadenado. (...) Seguro que tiene hambre porque a veces lo muerde" (Ajuar funerario: 85). Las abuelas contribuyen, asimismo, a angustiar a sus nietos con fantasías de culpa. Es el caso de "Longino", donde la mujer enseña a su nieto su crucifijo aterrador señalándole que, al mentir, "le aprietas la corona y le clavas más las espinas" (Ajuar funerario: 79)

Pero entre las mujeres malvadas de Ajuar funerario sobresale, sin duda, la monja monstruo, que él mismo describe como "su modesta contribución a la literatura de terror" (Trazegnies) y que se remonta a sus recuerdos de infancia: "Cuando era niño estudié en un colegio de monjitas españolas y descubrí que las monjas eran como los policías. Es decir, que había monjas buenas y monjas malas. Las monjitas buenas eran buenísimas y ya me ocupé de ellas en un libro anterior -El Descubrimiento de España (1996)-, pero las monjas malas eran unas hijas de su purísima madre y por eso están todas en este libro. Especialmente una: la que me torturaba sumando quebrados y dividiendo con decimales" (Muñoz). Sin duda, esta última es un trasunto de la pesadillesca Madre Dolores, protagonista de "El cuarto oscuro".

No olvidamos, sin embargo, que la literatura gótica, de marcado carácter anticatólico en sus orígenes, ha contado con bastantes mojas terroríficas -Juan Montalvo y Juana Manuela Gorriti ofrecen buenos ejemplos de este hecho en las literaturas hispánicas-, que, tras haber sido emparedadas en sus celdas, vuelven a la vida sedientas de venganza.

Así, en "La casa de reposo" la madre superiora se descubre como una fría asesina; "Las reliquias" acaba con un acto de canibalismo colectivo -que nos recuerda al de la niña protagonista de "Las manos de la fundadora"- y "De incorruptis" presenta una monstruosa monja zombi. Entre todos ellos, destacamos por su humor "Dulces de convento", donde las monjas acaban metamorfoseadas en sus perros guardianes, provocando el siguiente comentario del narrador: "no descansaré hasta acabar con esas alimañas. Especialmente con la más gorda, la que se santiguaba mientras comía” (Ajuar funerario: 33). 


\section{LA PÉRDIDA DE IDENTIDAD}

Uno de los terrores más extendidos en los seres humanos se encuentra relacionado con la pérdida de la propia identidad. De ahí la catoptrofobia -miedo a mirarse en los espejos-, la automatonofobia -miedo a las estatuas- o la amnesifobia -miedo a perder la memoria-. Estatuas, retratos, ojos sin vida y espejos abundan en los espacios representados en Ajuar funerario, provocando el desasosiego de unos personajes que ven cómo pierden progresivamente la noción de sí mismos. Así ocurre en los salones cerrados y así se repite a través de los monstruosos dobles presentes en el volumen: el hermano zombie de "Ya no quiero a mi hermano", el marido alien de "El extraño" o el mellizo enquistado en la espalda del protagonista en "El parásito". En la misma línea, aunque compartiendo una sola naturaleza, se encontrarían el trasnochador que, en "Monsieur le revenant" se convierte en vampiro por visionar "uno de esos canales por cable que sólo pasan películas de terror de bajo presupuesto" (Ajuar funerario: 32); el metamorfoseado en hombre lobo a causa de una máscara en "Halloween", "El monstruo de la laguna verde", producto de un acné mal curado" o, finalmente, la devoradora sexual que deviene una "Gorgona" en el cuento homónimo.

La incertidumbre atormenta asimismo a personajes que no saben si están vivos o muertos, como los niños protagonistas de "Día de difuntos", "La soledad", "Aire de familia" y, especialmente, la fantasma de "No hay que hablar con extraños", condenada a vivir en el interregno entre la vida y la muerte por aceptar los caramelos de Agustín, rodeada en su inocencia de "muchas cosas que cortan y queman y pinchan" (Ajuar funerario: 46).

\section{CONCLUSIÓN}

Llego así al final de un camino en el que espero haber demostrado tanto la buena salud del microrrelato de terror como la incuestionable calidad de Ajuar funerario, paradigma de la renovación actual del género y prueba fehaciente de las múltiples y gratas sorpresas que la minificción seguirá deparándonos en los próximos años.

\section{BIBLIOGRAFÍA CITADA}

Areta, José María (2008). "Claves de Ajuar funerario", en http://sincronia.cucsh.udg.mx/Aretasummer08.htm (12/7/208).

Arias García, Benito (comp.) (2004). Grandes minicuentos fantásticos. Madrid, Alfaguara.

Baldick, Chris (ed.) (1992). The Oxford Book Of Gothic Tales. Oxford, Oxford University Press. 
Barros, Pía (2000) Ropa usada. Santiago, Asterión.

Benítez Reyes, Felipe (1994) Un mundo peligros (relatos 1982-1994). Valencia, PreTextos.

Borges, Jorge Luis y Adolfo Bioy Casares (1957). Cuentos breves y extraordinarios. Buenos Aires, Losada.

Borges, Jorge Luis, Adolfo Bioy Casares y Silvina Ocampo (1989) Antología de la literatura fantástica. Barcelona, Edhasa [1940].

Bravo, Víctor (2005) "El miedo y la literatura", Anales de literatura hispanoamericana, $\mathrm{n}^{\mathrm{o}}$ 34: 13-17.

Briggs, Julia (1977) Night Visitors: The Rise and Fall of the English Ghost Story. London, Faber.

Cortázar, Julio (1980). “La muñeca rota”, en Último round. México, Siglo XXI: 248271. [1969].

-. (1994) "Notas sobre lo gótico en el Río de la Plata", en Obra crítica. 3. Saúl Yurkievich (ed.). Madrid, Alfaguara: 79-87 [1975]

Chiappe, Doménico (2008) "Fernando Iwasaki: El terror infantil que perfora los cuentos". TalCual. 30 de Mayo de 2004. En <http://www.letralia.com/ciudad/chiappe/ 16.htm> (15/3/2008).

Day, William (1985) In the Circles of Fear and Desire: A Study of Gothic Fantasy. Chicago, University of Chicago Press.

Díez, Luis Mateo (2002) Los males menores. Fernando Valls intr. Madrid, Espasa Calpe.

Echeverría, Rosa María (2004) "Iwasaki transforma el terror en arte en Ajuar funerario", $A B C, 1$ de junio, en http://www.abc.es/hemeroteca/historico-01-062004/abc/Cultura/iwasaki-transforma-el-terror-en-arte-en-su-obra-ajuar-funerario_ 9621798546196.html (15/3/2008).

"Fernando Iwasaki en pocas palabras" (2007), blog de Diario sin nombre, 8 de diciembre. En http:/ /eldiariosinnombre.blogspot.com/2007/12/fernando-iwasaki-en-pocaspalabras.html (15/03/2008).

Fuentes, Carlos (2004) Inquieta compañía. Madrid, Alfaguara.

Francés, José Antonio (2007). Miedo me da (78 relatos de humor y espanto). Sevilla, Algaida.

Frank, Frederick (1987) The First Gothics: A Critical Guide to the English Gothic Novel. New York.Garland Publishing. 
Freire, Espido (2003) Cuentos malvados. Madrid, Punto de Lectura.

García, Luis (2007) “Fernando Iwasaki”. Fábula. Revista literaria n 14: 58-62. En <http://www.unirioja.es/servicios/sp/ej/fabula/textos/fab014058.shtml> (15/3/2008).

Hoffman, Gerald (1982) "The Fantastic in Fiction: Its Reality Status, Its Historical Development and its Transformation in Postmodern Narration", Real, $\mathrm{n}^{\circ}$ 1: 267-364.

Iwasaki, Fernando (1993) A Troya, Helena. Bilbao, Los Libros de Hermes.

-. (1994). Tres noches de corbata Huelva, Diputación de Huelva [1987].

-. (1998) "Noche de brujas en Baltimore", Clarín, no 16: 56-58.

-. (2004) Ajuar funerario. Madrid, Páginas de Espuma.

-. (2005) Neguijón. Madrid, Alfaguara.

- (2006) "Mi primera experiencia textual”, en El arquero inmóvil. Nuevas poéticas sobre el cuento. Eduardo Becerra ed. Madrid, Páginas de Espuma, 79-81.

-. (2007) Inquisiciones peruanas. Madrid, Páginas de Espuma [1994]

J.A. (2004) "Iwasaki publica «Ajuar funerario»: «Desde Bécquer a Borges hay una gran tradición de terror en español»". $A B C, 23$ de mayo. En http://www.abc.es/hemeroteca/historico-23-05-2004/sevilla/Sevilla/iwasaki-publica-ajuarfunerario-desde-becquer-a-borges-hay-una-gran-tradicion-de-terror-en-espa\%C3\% $\mathrm{B} 1 \mathrm{ol}$ 9621652444422.html (15/3/2008).

Jackson, Rosemary (1981) Fantasy: the Literature of Subversion. London, Routledge.

Matute, Ana María (1994) Los niños tontos. Barcelona, Destino [1956].

Merino, José María (2005) Cuentos del libro de la noche. Madrid, Alfaguara.

Muñoz, Miguel Ángel (2007) “El síndrome de Chéjov”. Entrevista a Fernando Iwasaki”. En http://elsindromechejov.blogspot.com/2007/11/fernando-iwasaki-quiero-quemis-cuentos.html (17/3/2008).

Neuman, Andrés (2006) Alumbramiento. Madrid, Páginas de Espuma.

Paz Soldán, Edmundo (2004) "Las máscaras de la nada" [1990], en Desencuentros. Madrid, Alfaguara.

Plinio el Joven (2005) Cartas. Madrid, Gredos.

Pont, Jaume (ed.) (1999) Brujas, demonios y fantasmas en la literatura fantástica hispánica. Lleida, Edicions Universitat de Lleida.

Praz, Mario (1968) "Introductory Essay", en Three Gothic Novels. New York, Penguin.

Punter, David (1990) The Romantic Unconscious: A Study in Narcissim and Patriarchy. New York, New York University Press. 
Roas, David (2007). Horrores cotidianos. Palencia, Menoscuarto.

Shua, Ana María (2004). Temporada de fantasmas. Madrid, Páginas de Espuma.

Tellería, Alejandro (2007). "Si folláramos más, escribiríamos menos", The Barcelona review: Revista internacional de narrativa breve contemporánea noviembre-diciembre, $\mathrm{n}^{\circ} 45$. En http://www.barcelonareview.com/45/s_fi.htm (15/3/2008).

Trazegnies, Leopoldo de (2004) Ajuar funerario. Biblioteca virtual de literatura. 24 de julio. http://www.trazegnies. arrakis.es/iwasaki3.html (15/3/2008).

Todorov, Tzvetan (1987) Introducción a la literatura fantástica. México, Premiá [1970].

Valadés, Edmundo (ed.) (1976). El libro de la imaginación. México, FCE, 1976.

Williams, Anne (1995) Art of Darkness: A Poetics of Gothic. Chicago, University of Chicago Press. 